\title{
Characterization of an autotransporter adhesin protein shared by Burkholderia mallei and Burkholderia pseudomallei
}

\author{
Eric R Lafontaine ${ }^{1 *}$, Rachel Balder ${ }^{1}$, Frank Michel $^{2}$ and Robert J Hogan ${ }^{2}$
}

\begin{abstract}
Background: Autotransporters form a large family of outer membrane proteins specifying diverse biological traits of Gram-negative bacteria. In this study, we report the identification and characterization of a novel autotransporter gene product of Burkholderia mallei (locus tag BMA1027 in strain ATCC 23344).

Results: Database searches identified the gene in at least seven B. mallei isolates and the encoded proteins were found to be $84 \%$ identical. Inactivation of the gene encoding the autotransporter in the genome of strain ATCC 23344 substantially reduces adherence to monolayers of HEp-2 laryngeal cells and A549 type II pneumocytes, as well as to cultures of normal human bronchial epithelium (NHBE). Consistent with these findings, expression of the autotransporter on the surface of recombinant $E$. coli bacteria increases adherence to these cell types by $5-7$ fold. The gene specifying the autotransporter was identified in the genome of 29 B. pseudomallei isolates and disruption of the gene in strain DD503 reduced adherence to NHBE cultures by $61 \%$. Unlike B. mallei, the mutation did not impair binding of B. pseudomallei to A549 or HEp-2 cells. Analysis of sera from mice infected via the aerosol route with B. mallei and B. pseudomallei revealed that animals inoculated with as few as 10 organisms produce antibodies against the autotransporter, therefore indicating expression in vivo.
\end{abstract}

Conclusions: Our data demonstrate that we have identified an autotransporter protein common to the pathogenic species B. mallei and B. pseudomallei which mediates adherence to respiratory epithelial cells and is expressed in vivo during the course of aerosol infection.

\section{Background}

Autotransporter proteins are the largest known family of virulence factors expressed by Gram-negative bacteria and play prominent roles in processes such as invasion [1], serum resistance [2,3], phospholipolysis [4-6], cytotoxicity [7], adherence [8,9], survival within eukaryotic cells [10], intracellular motility [11], cell-to-cell aggregation [12,13], and biofilm formation $[14,15]$. These molecules display conserved structural features including an N-terminal surface-exposed domain responsible for the biological function and a hydrophobic C-terminus that tethers the autotransporter to the outer membrane $(\mathrm{OM})$. Based on the structure of the C-terminus, autotransporters can be classified as conventional or oligomeric [16-21]. The C-terminus

\footnotetext{
* Correspondence: elafon10@uga.edu

'Department of Infectious Diseases, University of Georgia College of Veterinary Medicine, 30602 Athens, GA, USA

Full list of author information is available at the end of the article
}

of conventional autotransporters consists of $\sim 300$ amino acids (aa) forming 10-12 antiparallel $\beta$-strands, while that of oligomeric autotransporters is substantially shorter $(\sim 70$ aa) and specifies only $4 \beta$-strands. Because of their structure and role in virulence, autotransporters are attractive targets for developing countermeasures against pathogenic organisms. Large portions of autotransporters are located on the bacterial surface and therefore readily accessible for recognition by the immune system. Additionally, autotransporters play important roles in pathogenesis, thus targeting them may hinder the ability to cause disease. This hypothesis is supported by several studies demonstrating the effectiveness of autotransporter-based countermeasures. For example, immunization with Neisseria meningitidis NadA elicits antibodies (Abs) binding to the bacterial surface and promoting complement-mediated killing $[22,23]$, which is key to protection against this organism. Antibodies against Haemophilus influenzae Hap 
block adherence to epithelial cells and immunization with Hap protects mice in nasopharyngeal colonization studies [24,25]. Vaccination with the Proteus mirabilis autotransporter cytotoxin Pta yields Abs that not only reduce bacterial burden in a murine urinary tract infection model, but also neutralize the cytotoxic activity of Pta for bladder cells [26]. Moreover, Bordetella pertussis Pertactin, an autotransporter adhesin, is a component of licensed vaccines for whooping cough (http://www. cdc.gov/vaccines/pubs/pinkbook/downloads/pert.pdf).

Burkholderia mallei and Burkholderia pseudomallei are closely related Gram-negative organisms for which developing efficacious countermeasures is highly desirable. Both species are classified as Tier 1 agents by the U.S. Federal Select Agent Program because of concerns regarding their use as bioweapons, especially since $B$. mallei has been utilized in this manner on more than one occasion [27-31]. Burkholderia mallei is a host-adapted pleomorphic coccobacillus that does not persist in the environment outside of its natural equine reservoir. The bacterium causes the highly contagious zoonotic disease glanders, which primarily affects horses, and is endemic to parts of Asia, Africa, South America and the Middle East [27,32-38]. In humans, infection typically occurs via the cutaneous or aerosol route upon contact with infected animals. Clinical manifestations include fever, pneumonia, necrosis of the trachea and bronchi, bacteremia, and dissemination of B. mallei to organs where it causes necrotizing abscesses. Burkholderia pseudomallei is a saprophyte of wet soils and is endemic to countries bordering the equator. The organism can infect most mammals and causes the disease melioidosis in humans, a febrile illness that varies greatly in its clinical presentation. Disease states range from flu-like malaise to septicemia, chronic abscess formation in deep tissues, or bacteremic pneumonia [33,39-45]. Infection is generally acquired by percutaneous inoculation, ingestion and inhalation of aerosols, and the risk of contracting disease is proportionate to the concentration of B. pseudomallei in soil. Burkholderia pseudomallei is a leading cause of sepsis and bacteremic pneumonia in Southeast Asia and Australia, and melioidosis is increasingly recognized as an emerging infectious diseases in many tropical regions of the world $[40,46,47]$.

Glanders and melioidosis have high mortality rates (up to 50\%) despite aggressive antimicrobial therapy. The recommended treatment involves the use of ceftazidime and meropenem (intensive phase) and TMP-SMX and coamoxiclav (eradication phase) for several months [48]. Response to treatment is slow and eradication of the agents is difficult, often resulting in protracted alternating bouts of remission and exacerbation. There are no vaccines available to protect against either Burkholderia species. Clearly, there is a need to identify and characterize targets for developing countermeasures for these organisms. The genomes of B. mallei and B. pseudomallei have been reported to encode multiple autotransporters [49-51]. In this study, we examined one of these gene products and evaluated it role in adherence in vitro and virulence in a mouse aerosol model of infection.

\section{Results}

Identification of a gene encoding a potential autotransporter adhesin shared by $B$. mallei and B. pseudomallei

Comparative sequence analyses identified a gene product in the published genome of B. mallei strain ATCC 23344 (locus tag \# BMA1027) that resembles the adhesins Yersinia enterocolitica YadA [2,21,52], Moraxella catarrhalis Hag [8,53,54], B. pseudomallei BoaA and BoaB [55], and B. mallei BoaA [55]. These molecules belong to the oligomeric coiled-coil adhesin (Oca) sub-family of oligomeric autotransporter proteins and have a characteristic modular organization consisting of: (i) a surfaceexposed region specifying adhesive properties termed passenger domain, (ii) a short linker region predicted to form an $\alpha$ helix, and (iii) a hydrophobic C-terminus composed of four $\beta$-strands anchoring the autotransporter in the $\mathrm{OM}$ designated transporter domain [16,19-21]. As shown in Figure 1A, BMA1027 is predicted to possess these structural features.

Searches using the Pfam database revealed that the region encompassing aa 936-1012 of BMA1027 shows similarity to a YadA anchor domain (PF3895.10; expect value of $6.3 \mathrm{e}^{-22}$ ), which is present in most Oca and described as important for oligomerization and targeting autotransporters to the OM. Pfam searches also indicated that BMA1027 contains four YadA stalk domains (PF05662, formerly designated HIM; expect values ranging from $2.2 \mathrm{e}^{-4}$ to $1.5 \mathrm{e}^{-9}$; grey crosses in Figure $1 \mathrm{~A}$ ). This motif is associated with invasins and haemagglutinins and is present in YadA as well as Hag $[2,8,52,53]$. YadA contains one stalk domain, which has been shown to be necessary for protein stability and adhesive properties. Further sequence analysis revealed that the passenger domain of BMA1027 specifies repeated aa motifs, a trait noted in several oligomeric autotransporters including YadA [2,52], Hag [8,53], BoaA and BoaB [55], the $B$. pseudomallei biofilm factor BbfA [56], and the $M$. catarrhalis UspA1, UspA2, and UspA2H proteins [57-60]. As illustrated in Figure $1 \mathrm{~A}$, the passenger domain of BMA1027 contains nine copies of the 5-mer SLSTS (red triangles) and several repeated elements beginning with residues NSTA (colored boxes). Additional characteristics of the predicted protein are listed in Table 1.

The published genomic sequence of the B. pseudomallei strain K96243 was found to specify a BMA1027 ortholog (locus tag \# BPSL1631, Figure 1B) that is $89 \%$ identical to that of B. mallei ATCC 23344. The BMA1027 ortholog 


\section{A. B. mallei ATCC23344 BMA1027}

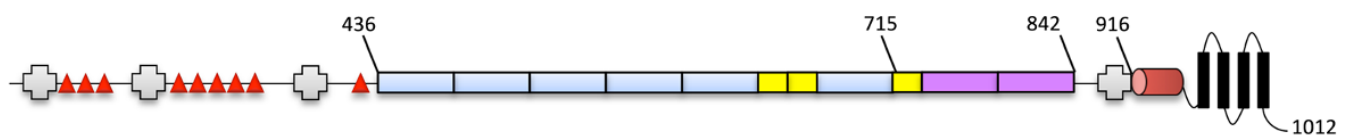

B. B. pseudomallei K96243 BPSL1631

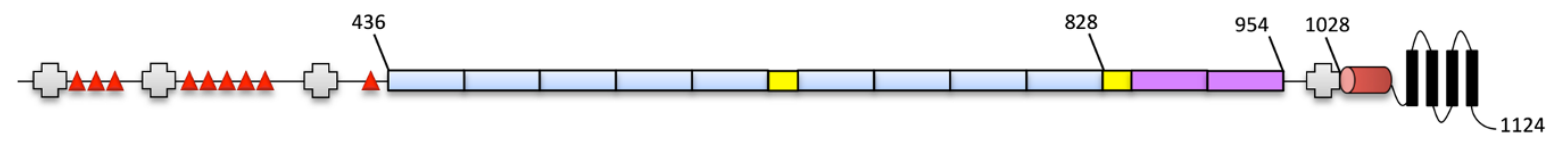

C. B. pseudomallei DD503

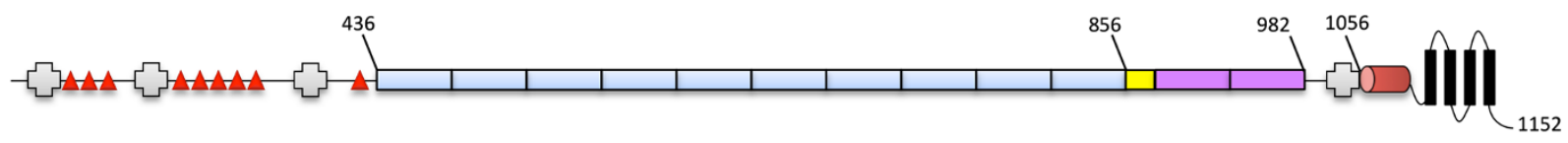

Passenger domain (surface-exposed)
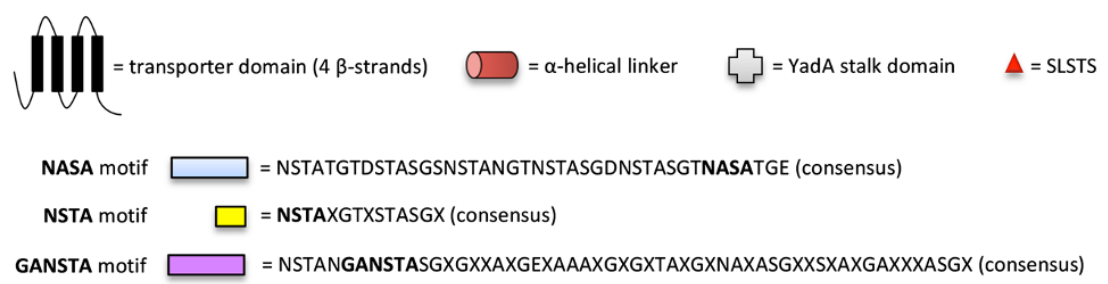

Figure 1 Structural features of BMA1027 and orthologous gene products. Different regions of the protein encoded by B. mallei ATCC 23344 BMA1027 (A), B. pseudomallei K96243 BPSL1631 (B) and the B. pseudomallei DD503 BMA1027 ortholog (C) are depicted with the positions of residues defining selected domains. Transporter domains (OM anchors) and helical linkers were identified using the PSIPRED secondary structure prediction algorithm. The colored boxes, red triangles, and grey crosses show the relative position and number of repeated aa motifs.

was sequenced from the B. pseudomallei strain used in our laboratory, DD503, and was predicted to encode a protein that is $97 \%$ and $87 \%$ identical to that of B. pseudomallei $\mathrm{K} 96243$ and B. mallei ATCC 23344, respectively (Figure 1C). Database searches with the NCBI genomic
BLAST service also identified orthologs in several B. pseudomallei and B. mallei isolates. Seven B. mallei and twenty-nine $B$. pseudomallei strains for which sequences are available through the service were found to have the gene. Characteristics of these ORFs are listed in the

Table 1 Characteristics ${ }^{\mathrm{a}}$ of BMA1027 orthologous genes and their encoded products

\begin{tabular}{|c|c|c|c|c|}
\hline Strain $^{b}$ & Locus tag & Predicted protein (aa) & MW (kDa) & Potential signal sequence cleavage site \\
\hline \multicolumn{5}{|l|}{ B. pseudomallei } \\
\hline 1026b/DD503* & BP1026B_11575 & 1,152 & 107.4 & $\mathrm{ASA}^{37 \mathbf{v}} \mathrm{G}, \mathrm{AMA}^{69 \mathbf{\nabla}} \mathrm{A}$ \\
\hline K96243 & BPSL1631 & 1,124 & 104.8 & $\mathrm{ASA}^{37 \mathbf{v}} \mathrm{G}, \mathrm{AMA}^{69 \mathbf{\nabla}} \mathrm{A}$ \\
\hline \multicolumn{5}{|l|}{ B. mallei } \\
\hline ATCC 23344 & BMA1027 & 1,012 & 94.7 & $\mathrm{ASA}^{37 \mathbf{v}} \mathrm{G}, \mathrm{AMA}^{69 \mathbf{\nabla}} \mathrm{A}$ \\
\hline
\end{tabular}

${ }^{\mathrm{a}}$ Sequence analyses were performed using Vector NTI (Life Technologies ${ }^{\mathrm{TM}}$ ) and online tools available through the ExPASy Bioinformatics Resources Portal.

${ }^{\mathrm{b}}$ Genomic sequences are available through the NCBI genomic BLAST service.

${ }^{\mathrm{C}}$ The putative signal sequence cleavage sites were determined using the SignalP 4.1 server.

*The B. pseudomallei strain DD503 is a derivative of isolate 1026b in which the AmrAB-OprA antibiotic efflux pump has been deleted to facilitate mutant construction [61]. The BMA1027 orthologs of strains DD503 and 1026b are identical (confirmed by nucleotide sequence analysis, data not shown). 
Additional files 1 and 2. Overall, the proteins are $87-100 \%$ identical and differ primarily in the number and/or arrangement of SLST repeats, YadA stalk domains, and/or NSTA elements in their passenger domains. Based on these results, we conclude that BMA1027 orthologs are well-conserved gene products shared by $B$. mallei and $B$. pseudomallei. While preparing this article, Campos and colleagues published a report in which they functionally characterized autotransporter genes specified by the $B$. pseudomallei strain 1026b [51]. One of these molecules corresponds to the BMA1027 ortholog (locus tag \# BP1026B_1575), which the authors designated bpaC. Henceforth, BMA1027 and orthologs will be referred to as BpaC.

\section{Expression and functional properties of the $\mathrm{BpaC}$ protein in $E$. coli}

Because of sequence and structural similarities to known bacterial adhesins, we speculated that $\mathrm{BpaC}$ mediates adherence to epithelial cells. To test this hypothesis, the bpaC gene of B. pseudomallei DD503 was cloned and expressed in the E. coli strain EPI300. This organism does not adhere well to epithelial cells [8,53,55,62] and therefore provides a suitable heterologous genetic background to study the adherence properties of BpaC. To verify protein expression, whole cell lysates were prepared from E. coli EPI300 harboring the plasmid pCC1.3 (control) or pCCbpaC (specifies B. pseudomallei DD503 bpaC) and analyzed by western blot. Figure 2A shows that $\alpha-\mathrm{BpaC}$ Abs (directed against aa 392-1098, part of surface-exposed passenger domain) react specifically with a band of $100-\mathrm{kDa}$ in E. coli expressing the bpaC gene (lane 2), which is consistent with the predicted molecular mass of the gene product (Table 1). The Abs also specifically reacted with an antigen of high molecular weight $(\geq 250 \mathrm{kDa})$, which likely corresponds to an oligomeric form of BpaC. Immunofluorescence-labeling of non-permeabilized $E$. coli cells was used to demonstrate that $\mathrm{BpaC}$ is displayed on the surface of recombinant bacteria. As shown in Figure 2B, E. coli carrying pCCbpaC is labeled by $\alpha$-BpaC Abs while recombinant bacteria harboring the control plasmid pCC1.3 are not. Staining of nucleic acids with DAPI verified that equivalent numbers of bacteria were examined.

Quantitative adherence assays revealed that E. coli expressing BpaC binds to HEp-2 (laryngeal) and A549 (lung) human epithelial cells at levels 7 - and 5-fold greater than bacteria carrying pCC1.3, respectively (Figure 2C). BpaC expression was also found to increase adherence by 7 -fold to normal human bronchial epithelium (NHBE) cultured

\section{A. Western blot}

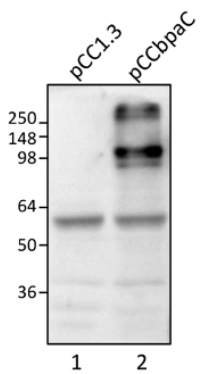

C. Adherence assays HEp2 (laryngeal)

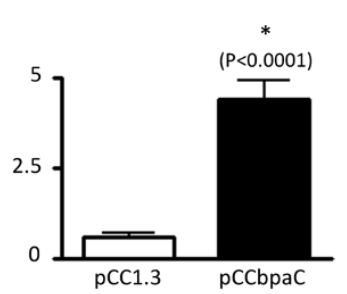

\section{B. Immunofluorescence staining}

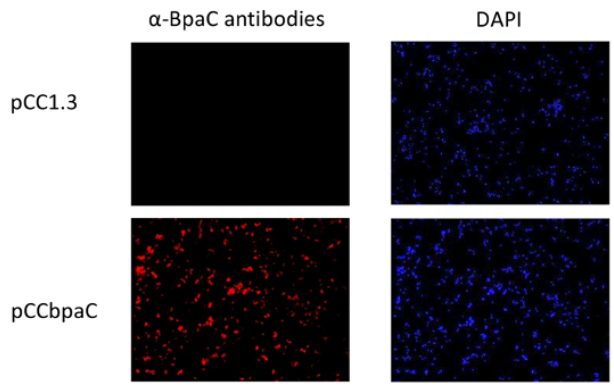

A549 (lung)

Normal human bronchial epithelium (NHBE)

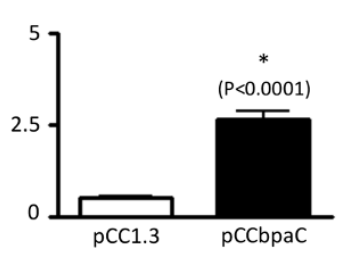

Figure 2 Analysis of $\boldsymbol{E}$. coli recombinant strains. Panel A: Whole cell lysates were resolved by SDS-PAGE, transferred to PVDF membranes and analyzed by western blot with Abs against BpaC. Lane 1, E. coli (pCC1.3); lane 2, E. coli (pCCbpaC). MW markers are shown to the left in kilodaltons. Panel B: Non-permeabilized E. coli strains were fixed onto glass slides and fluorescently-labeled with DAPI (blue) and with a-BpaC Abs (red). Bacteria were visualized by microscopy using a Zeiss LSM 510 Meta confocal system. Representative microscopic fields are shown. Panel C: E. coli strains were incubated with epithelial cells for 3 -hr. Cells were then washed to remove unbound bacteria, lysed, diluted and spread onto agar plates to enumerate bound bacteria. The results are expressed as the mean percentage ( \pm standard error) of inoculated bacteria attached to epithelial cells. Asterisks indicate that the increased adherence of $E$. coli ( $\mathrm{pCCbpaC),} \mathrm{compared} \mathrm{to} \mathrm{that} \mathrm{of} \mathrm{E.} \mathrm{coli} \mathrm{carrying} \mathrm{the} \mathrm{control} \mathrm{plasmid} \mathrm{pCC1.3,} \mathrm{is}$ statistically significant ( $P$ value shown in parentheses). Adherence assays were performed in duplicate on at least 4 independent occasions. 
in an air-liquid interface system, which has been shown to represent an environment similar to the airway lumen in vivo $[54,63,64]$. These results demonstrate that $\mathrm{BpaC}$ mediates adherence to respiratory epithelial cells. Burkholderia pseudomallei and B. mallei are facultative intracellular bacteria that replicate within several eukaryotic cell types. Moreover, autotransporter adhesins frequently perform additional functions including invasion [1], intracellular motility [11], and survival inside host cells [10]. For these reasons, we examined the ability of E. coli expressing $\mathrm{BpaC}$ to invade epithelial cells and survive within murine macrophages. The results of these experiments indicated that $\mathrm{BpaC}$ does not substantially increase invasion of epithelial cells, phagocytosis of recombinant bacteria by J774A.1 murine macrophages, or survival inside these immune cells (data not shown).

\section{In vitro characterization of B. mallei and B. pseudomallei mutant strains}

To study the functional properties of the $b p a C$ gene product in Burkholderia, we constructed isogenic bpaC mutants of B. pseudomallei DD503 and B. mallei ATCC 23344. Whole cell lysates and sarkosyl-insoluble OM proteins were prepared from these strains and analyzed by western blot to verify lack of $\mathrm{BpaC}$ expression in the mutants. However, $\alpha-\mathrm{BpaC}$ Abs did not react with protein preparations of parent or mutant strains (data not shown). Other methods such as immunoprecipitation and immunofluorescence-labeling also failed to detect $\mathrm{BpaC}$ expression. These results indicate that the bpaC gene is expressed at very low levels under the laboratory growth conditions we used to propagate the organisms.

Because adherence assays with recombinant bacteria revealed that $\mathrm{BpaC}$ expression increases the binding of E. coli to NHBE cultures and monolayers of A549 and HEp-2 cells (Figure 2C), we compared the ability of Burkholderia parent and bpaC mutant strains to attach to these respiratory cells. Figure $3 \mathrm{C}$ shows that inactivation of the bpaC gene in B. pseudomallei DD503 affects adherence to NHBE cultures, reducing levels by $61 \%$. The B. pseudomallei mutant bound to A549 and HEp-2 cells at wild-type levels. The $\mathrm{bpaC}$ mutation significantly impaired the ability of $B$. mallei ATCC 23344 to attach to A549 cells (66\% reduction, Figure 3D), HEp-2 monolayers (72\% reduction, Figure $3 \mathrm{E})$, and NHBE cultures (66\% reduction, Figure $3 \mathrm{~F})$. These results demonstrate

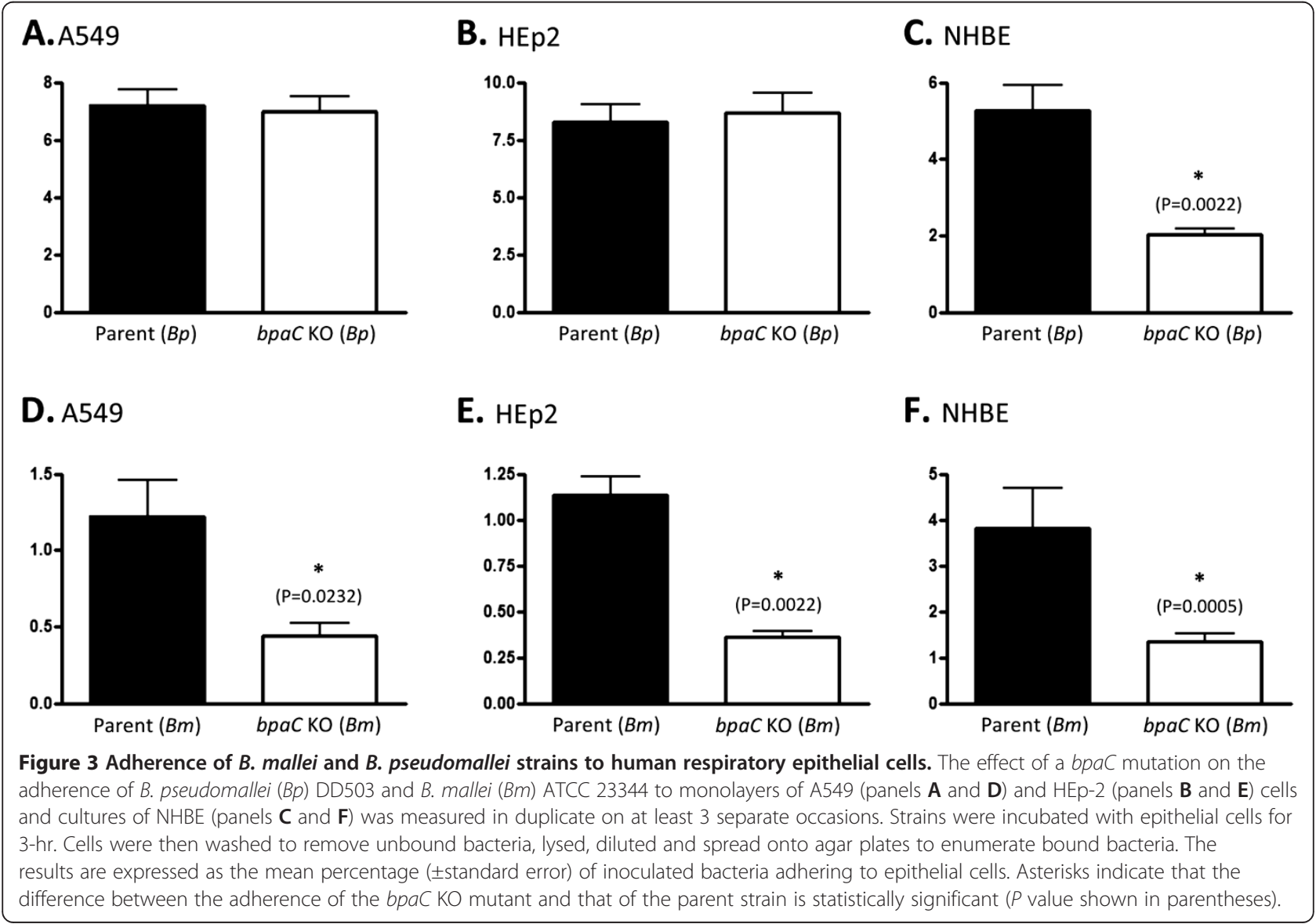


that the $b p a C$ gene product contributes to the adherence of B. mallei and B. pseudomallei to epithelial cells derived from the human respiratory tract.

As stated earlier, autotransporter adhesins often perform multiple biological functions including invasion [1] and survival within host cells [10]. In addition, B. pseudomallei and $B$. mallei are facultative intracellular pathogens that effectively replicate inside professional phagocytic cells. Therefore, we measured the ability of Burholderia mutant and parent strains to invade epithelial cells (A549 and HEp-2) and replicate within J774A.1 murine macrophages. The results of these experiments indicated that the bpaC mutation does not cause a defect in invasion of epithelial cells, phagocytosis of recombinant bacteria by J774A.1 murine macrophages, or growth inside these cells (data not shown). The bpaC mutants did not show defects in resistance to the bactericidal activity of normal human serum (data not shown), which is another biological function commonly associated with Oca autotransporters $[2,3,19,65,66]$.

Virulence of $B$. mallei and B. pseudomallei mutant strains and $\mathrm{BpaC}$ expression in vivo

To determine whether $\mathrm{BpaC}$ contributes to virulence, we calculated the median lethal dose $\left(\mathrm{LD}_{50}\right)$ of $B$. pseudomallei and B. mallei mutant strains in a mouse model of aerosol infection. The model entails the use of a Microsprayer ${ }^{\circ}$ to deliver bacteria directly into the murine lungs [67]. The device generates aerosol particles from the tip of a bent, 23-gauge nebulizing tube attached to a high-pressure stainless steel syringe that contains bacteria. BALB/c mice were anesthetized and placed in a custom-designed acrylic holder inside a Class II Biosafety cabinet. A modified pediatric otoscope equipped with a light source was then used to introduce the nebulizing tube portion of the Microsprayer into the trachea of animals, and 50- $\mu \mathrm{L}$ of bacterial suspension was aerosolized into the lungs by pushing the plunger of the high-pressure syringe. Following infection, mice were observed daily for clinical signs of illness and morbidity. As shown in Table 2, the bpaC mutation did not have an impact on the $\mathrm{LD}_{50}$ values of $B$. mallei ATCC 23344 or B. pseudomallei DD503. Tissues (i.e. lungs, spleen, liver) from mice that survived the acute phase of infection did not show differences in bacterial loads (data not shown). Based on these results, we conclude that the bpaC mutation does not affect the virulence of $B$. malle $i$ ATCC 23344 or B. pseudomallei DD503 via the aerosol route of infection.

To gain insight into the immune response to $\mathrm{BpaC}$ during infection, we tested sera from mice that survived aerosol challenge with B. mallei ATCC 23344 and

Table 2 Median lethal dose determination of B. mallei and B. pseudomallei WT and mutant strains

\begin{tabular}{|c|c|c|c|c|c|}
\hline Organism & Strain & Inoculating dose (CFU) & Group size & $\%$ death & $\mathrm{LD}_{50}$ (CFU) \\
\hline \multirow[t]{5}{*}{ B. mallei } & ATCC 23344 (WT) & 9,100 & 5 & 100 & \\
\hline & & 5,550 & 5 & 100 & \\
\hline & & 910 & 9 & 78 & 346 \\
\hline & & 455 & 5 & 40 & \\
\hline & & 91 & 9 & 11 & \\
\hline \multirow[t]{5}{*}{ B. mallei ${ }^{a}$} & bpaC KO (mutant) & 10,400 & 5 & 100 & \\
\hline & & 5,200 & 6 & 83 & \\
\hline & & 1,040 & 9 & 100 & 238 \\
\hline & & 520 & 5 & 40 & \\
\hline & & 104 & 9 & 22 & \\
\hline PBS (control) $)^{a}$ & & 0 & 5 & 0 & \\
\hline \multirow[t]{4}{*}{ B. pseudomalleib } & DD503 (WT) & 380,000 & 5 & 100 & \\
\hline & & 38,000 & 5 & 100 & 1,202 \\
\hline & & 3,800 & 5 & 100 & \\
\hline & & 380 & 5 & 0 & \\
\hline \multirow[t]{4}{*}{ B. pseudomalleib } & bpaC KO (mutant) & 350,000 & 5 & 100 & \\
\hline & & 35,000 & 5 & 100 & 1,107 \\
\hline & & 3,500 & 5 & 100 & \\
\hline & & 350 & 5 & 0 & \\
\hline PBS (control) $)^{b}$ & & 0 & 5 & 0 & \\
\hline
\end{tabular}

\footnotetext{
${ }^{a}$ mice were monitored daily for clinical signs of illness/morbidity for 10 days post-inoculation.
}

${ }^{b}$ mice were monitored daily for clinical signs of illness/morbidity for 6 days post-inoculation. 
B. pseudomallei 1026b [67] by ELISA for the presence of Abs against the adhesin. Panels A and B in Figure 4 show that mice inoculated with doses as low as $10 \mathrm{CFU}$ produced $\mathrm{Abs}$ against $\mathrm{BpaC}$, which in turn demonstrates that this autotransporter is expressed by both B. mallei and B. pseudomallei during infection.

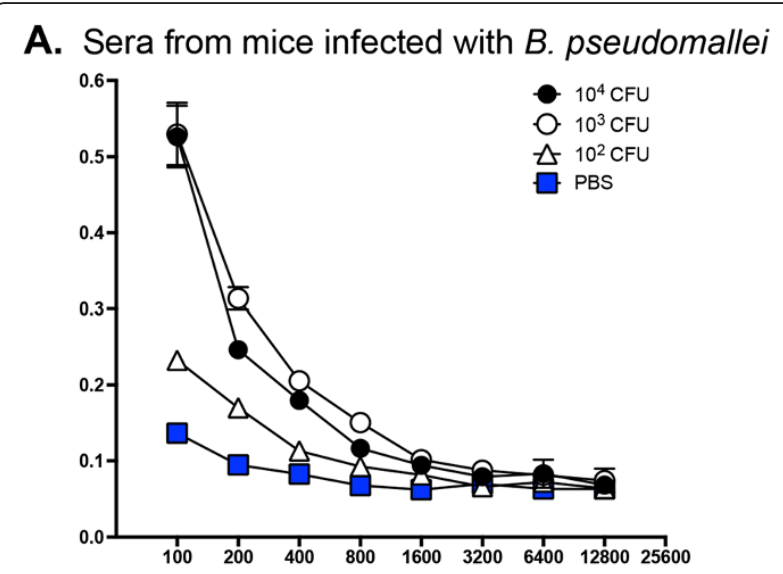

B. Sera from mice infected with B. mallei

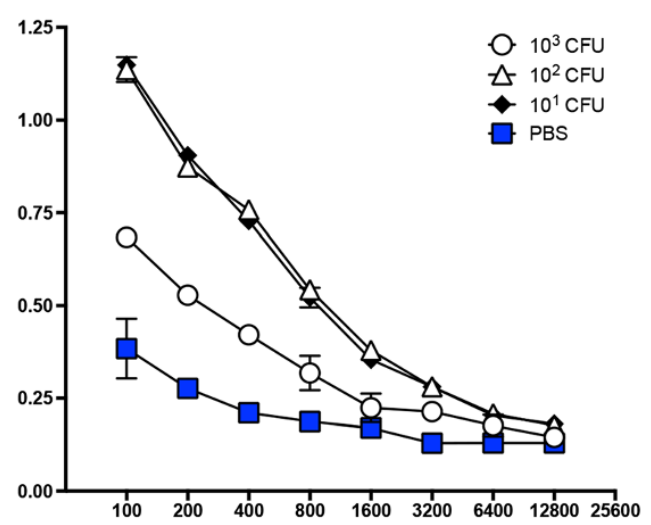

Figure 4 ELISA with sera from mice that survived aerosol challenge with various doses of $B$. pseudomallei $1026 \mathrm{~b}$ and B. mallei ATCC 23344. Serum samples were serially diluted and placed in duplicate wells of plates coated with purified His-tagged protein encompassing aa 392-1068 of B. pseudomallei 1026b BpaC Goat a-mouse Abs conjugated to HRP were used as secondary Abs. The $y$-axis shows absorbance at a wavelength of $650 \mathrm{~nm}$, which is indicative of antibody binding to antigens coating the plates. The $x$-axis represents two-fold dilutions of sera starting at 1:100 to $1: 12,800$. The results are expressed as the mean absorbance ( \pm standard deviation). Closed circles show sera from mice inoculated with $10^{4}$ B. pseudomallei bacteria (panel A). Open circles show sera from mice infected with $10^{3}$ organisms (panels $\mathbf{A}$ and $\mathbf{B}$ ). Open triangles show sera from mice inoculated with $10^{2}$ bacteria (panels $\mathbf{A}$ and $\mathbf{B}$ ). Closed diamonds show sera from mice infected with $10^{1}$ CFU of B. mallei ATCC 23344 (panel B). Blue squares represent sera from control mice that were inoculated with $50 \mu \mathrm{L}$ of PBS using the Microsprayer (panels A and B). Of note, sera from mice that survived acute infection by $B$. pseudomallei and B. mallei are described elsewhere [67].

\section{Discussion}

The genome of B. mallei ATCC 23344 has been reported to specify eight autotransporter gene products [49] and of these, only BoaA (adhesin, [55]) and BimA (intracellular motility protein, $[11,68]$ ) have been functionally characterized. Both are classified as oligomeric autotransporters because they possess a short $\mathrm{C}$-terminal transporter module predicted to form $4 \beta$-strands, which anchor the molecules on the bacterial surface. In the present study, we characterized a third B. mallei ATCC 2334 oligomeric autotransporter, BpaC (BMA1027). Comparative sequence analyses indicate that the gene product is conserved among $\mathrm{B}$. mallei isolates (see Additional files 1 and 2) and resembles members of the Oca (oligomeric coiled-coil adhesin) subfamily of oligomeric autotransporter proteins [16,19-21]. Consistent with this, inactivation of $b p a C$ in the genome of $B$. mallei ATCC 23344 reduces adherence to monolayers of A549 (lung) and HEp-2 (larynx) cells grown in submerged cultures (Figure $3 \mathrm{D}$ and $\mathrm{E}$, respectively). Though these cells are relevant to aerosol infection by $B$. mallei, they lack key features of the airway mucosa such as cilia and mucociliary activity. Ciliated cells contribute to preventing colonization of the respiratory tract by pathogenic agents by moving secretions (and trapped organisms) toward the laryngopharynx for expectoration or swallowing to the stomach (where the acidic $\mathrm{pH}$ neutralizes organisms). For these reasons, we measured the adherence of the $B$. mallei bpaC mutant to cultures of NHBE grown in an air-liquid interface system. These cultures mimic the structure and function of the airway mucosa as they form a pseudostratified epithelium with tight junctions, contain ciliated and mucus-producing goblet cells, and display mucociliary activity $[63,64]$. Quantitative assays using this system revealed that adherence of the bpaC mutant was reduced by $66 \%$ (Figure $3 \mathrm{~F}$ ).

Orthologs of BpaC were identified in 29 B. pseudomallei isolates (see Additional files 1 and 2). The genome of some of these strains has not been completed, resulting in the passenger domain and transporter module of $\mathrm{BpaC}$ seemingly specified by two different ORFs (e. g. B7210, 112, BPC006, 354e). Inactivation of bpaC in the genome of the B. pseudomallei strain DD503 caused a 2.6-fold reduction in adherence to NHBE cultures (Figure $3 C$ ), which is consistent with the phenotype of the $B$. mallei bpaC mutant (Figure 3F). However, the bpaC mutation did not affect adherence of B. pseudomallei to A549 or HEp-2 cells (Figure 3A and B, respectively). One possible explanation for this lack of effect is that other adhesins expressed by the B. pseudomallei DD503 bpaC mutant provide a high background of adherence to A549 and HEp-2 monolayers. For instance, BoaA and BoaB have been shown to mediate binding of B. pseudomallei DD503 to HEp-2 and A549 cells [55]. Moreover, it was recently demonstrated that the B. pseudomallei gene products $\mathrm{BpaA}, \mathrm{BpaB}, \mathrm{BpaD}, \mathrm{BpaE}$ 
and BpaF all play a role in adherence to A549 cells [51]. The genes encoding these molecules are present in the genome of strain DD503.

While preparing this article, Campos and colleagues published a study in which they demonstrate that $\mathrm{BpaC}$ is an adhesin for A549 cells [51]. The authors reported that a mutation in the bpaC gene of $B$. pseudomallei strain 340 causes an $\sim 10$-fold reduction in adherence. These results are in contrast with our data showing that a B. pseudomallei DD503 bpaC mutant binds to A549 cells at wild-type levels (Figure 3A). One possible explanation for this phenotypic difference is that we performed adherence assays using plate-grown bacteria, and infected A549 cells for 3 hours before washing off unbound $B$. pseudomallei and measuring cell-binding. Campos et al. used overnight broth cultures to inoculate A549 cells and infected monolayers for only 2 hours. The method used to construct mutants might have impacted the experimental outcome of adherence assays as well. In the present study, an internal portion of the bpaC ORF was replaced with a zeocin resistance marker and this mutation was introduced in the genome of $B$. pseudomallei DD503 via allelic exchange. In contrast, the bpaC gene of B. pseudomallei strain 340 was disrupted via co-integration of a large plasmid $(\sim 9-k b)$ in the genome [51]. It is unlikely that the strain background in which the mutations were constructed has any effect on the phenotype of bpaC mutants since strains DD503 [61] and 340 [69] are both antibioticsensitive derivatives of the same clinical isolate, B. pseudomallei 1026b. Despite these differences, our data constitute independent proof of the role of $\mathrm{BpaC}$ as an adhesin. These results are substantiated by showing that expression of $\mathrm{BpaC}$ on the surface of recombinant $E$. coli bacteria increases adherence to NHBE, A549 and HEp-2 cells (Figure 2).

Given the phenotype of mutants in assays with NHBE cultures and that adherence is a key step in pathogenesis by most infectious agents, we expected the bpaC mutation to reduce the virulence of $B$. mallei and/or B. pseudomal$l e i$ in a mouse model of aerosol infection. However, the results of our animal experiments indicate that the mutants are as virulent as wild-type strains (Table 2). Presumably, other adhesins expressed by the $b p a C$ mutants provide sufficient adherence to the murine airway mucosa to allow colonization at wild-type levels and for the normal course of disease to ensue. It is unlikely that the lack of phenotype we observed in vivo is due to non-expression of $\mathrm{BpaC}$. Though we discovered that B. pseudomallei DD503 and B. mallei ATCC 23344 do not produce detectable amounts of $\mathrm{BpaC}$ under routine laboratory growth conditions, ELISA with sera from mice that survived acute aerosol infection with the agents show that animals produce Abs against the protein (Figure 4A and B). Moreover, sera from horses with experimental glanders have been shown to contain high antibody titers against $\mathrm{BpaC}$ [70]. These results are particularly significant as horses are the natural host and reservoir for $B$. mallei and arguably the most relevant surrogate to study glanders. Together, these data demonstrate that $\mathrm{BpaC}$ is expressed in vivo and elicits the production of Abs during infection.

The infection model we used to examine the effect of the $b p a C$ mutation might have impacted the outcome of virulence experiments. This hypothesis is supported by the Campos et al. study in which they show that the bpaC mutation reduces the ability of $B$. pseudomallei strain 340 to disseminate and/or survive in the liver [51]. In these experiments, BALB/c mice were infected intranasally with $500 \mathrm{CFU}$ of the agent and bacterial loads in tissues were determined 48 hours post-infection. In contrast, we inoculated BALB/c mice intratracheally using a Microsprayer, which nebulizes bacteria directly into the lungs, infected animals with doses ranging from $10^{2}$ to $10^{5} \mathrm{CFU}$, and determined bacterial burden in survivors 6-10 days post-infection (Table 2). It is also known that the choice of bacterial strains [71], inoculation route [72], and animal background [73] can significantly affect the course of disease by B. pseudomallei and B. mallei. For example, the $\mathrm{LD}_{50}$ value of the same $B$. pseudomallei isolate has been shown to differ by several orders of magnitude in C57BL/6 mice and BALB/c mice [74]. Therefore, a complete understanding of the role of $\mathrm{BpaC}$ in pathogenesis may require the use of multiple infection models.

\section{Conclusion}

This study demonstrates that $\mathrm{BpaC}$ is an autotransporter protein, which mediates adherence of B. mallei and B. pseudomallei to host cells that are relevant to pathogenesis by the organisms. We show that $\mathrm{BpaC}$ is conserved among isolates of both Burkholderia species, is expressed in vivo, and elicits production of Abs during infection. Hence, BpaC displays many properties of an important virulence factor and potential target for developing countermeasures. Though our animal experiments indicate that a mutation in bpaC does not impact the virulence of B. mallei or B. pseudomallei, adherence to host surfaces is a key early step in pathogenesis by most infectious agents. To accomplish this, pathogenic organisms typically express multiple adhesins to ascertain host colonization. It is likely that disruption of multiple genes specifying adherence factors, including bpaC, will result in decreased virulence and clarify the role of the autotransporter in the pathogenesis of B. mallei and B. pseudomallei. Continued investigation of $\mathrm{BpaC}$ will yield important information regarding the complex biology and virulence of these organisms, and may contribute to development of comprehensive countermeasures targeting autotransporters and their roles in pathogenesis. 


\section{Methods}

Strains, plasmids, tissue culture cell lines and growth conditions

The strains and plasmids used in this study are listed in Table 3. For construction of the B. pseudomallei bpaC mutant, Low Salt Luria Bertani (LSLB) agar (Teknova) supplemented with antibiotics was utilized as selective medium. For all other experiments, B. pseudomallei was cultured on Trypticase Soy Agar (BD) at $37^{\circ} \mathrm{C}$. Brucella Agar (BD) supplemented with $5 \%$ glycerol was used to grow Burkholderia mallei at $37^{\circ} \mathrm{C}$. Where indicated, antibiotics were added to the culture media at the following concentrations: $7.5 \mu \mathrm{g} / \mathrm{mL}$ (for B. mallei) and $100 \mu \mathrm{g} / \mathrm{mL}$ (for $B$. pseudomallei) Polymixin B (MP Biomedicals), $7.5 \mu \mathrm{g} / \mathrm{mL}$ (for B. mallei) and $50 \mu \mathrm{g} / \mathrm{mL}$ (for B. pseudomallei) kanamycin (MP Biomedicals), $7.5 \mu \mathrm{g} / \mathrm{mL}$ (for B. mallei) and $100 \mu \mathrm{g} / \mathrm{mL}$ (for B. pseudomallei) zeocin ${ }^{\text {TM }}$ (Life Technologies $^{\mathrm{Ts}}$ ). Plate-grown bacteria (40-hr for B. mallei, 20-hr for B. pseudomallei) were used for all experiments. For conjugative transfer of plasmids from E. coli to Burkholderia, $\mathrm{MgSO}_{4}$ was added to culture media at a final concentration of $10 \mathrm{mM}$.

Escherichia coli was cultured at $37^{\circ} \mathrm{C}$ using LSLB supplemented with $15 \mu \mathrm{g} / \mathrm{mL}$ chloramphenicol, $50 \mu \mathrm{g} / \mathrm{mL}$ kanamycin, or $50 \mu \mathrm{g} / \mathrm{mL}$ zeocin, where indicated. For conjugation experiments, LSLB was supplemented with $10 \mathrm{mM} \mathrm{MgSO}_{4}$. For assays with $E$. coli clones carrying pCC1-based plasmids, the CopyControl ${ }^{\mathrm{Ts}}$ Induction Solution (epicentre ${ }^{\bullet}$ Illumina ${ }^{\circ}$ ) was added to LSLB as previously reported [9].

The cell lines HEp-2 (human laryngeal epithelium; ATCC CCL-23), A549 (type II alveolar epithelium; ATCC CCL85) and J774A.1 (murine macrophages; ATCC TIB67) were cultured as outlined by others [5,55]. Normal human bronchial epithelium (NHBE; LONZA) was expanded, cryopreserved and cultured in an air-liquid interface system as previously described $[54,63,64]$. The apical surface of the NHBE was exposed to air for a minimum of 3 weeks prior to use in adherence assays to ascertain proper cellular differentiation and the development of functional cilia.

\section{Recombinant DNA methodology}

Standard molecular biology techniques were performed as described elsewhere [79]. Genomic DNA was purified from Burkholderia using the Easy-DNA ${ }^{\mathrm{TM}}$ Kit (Life Technologies $\left.^{\mathrm{TM}}\right)$. Plasmid DNA was isolated with the QIAprep Spin Miniprep kit (QIAGEN). The Platinum ${ }^{\oplus} P f x$ DNA Polymerase (Life Technologies ${ }^{\mathrm{TM}}$ ) was used to amplify the 3.8-kb bpaC gene of B. pseudomallei DD503 with

Table 3 Strains and plasmids

\begin{tabular}{|c|c|c|}
\hline Strain/plasmid & Description & Reference \\
\hline \multicolumn{3}{|l|}{ B. pseudomallei } \\
\hline DD503 & Parental strain; polymixin B resistant, zeocin sensitive, kanamycin sensitive (derived from clinical isolate 1026b) & {$[61]$} \\
\hline bpaC KO & Isogenic bpaC mutant strain of DD503; polymixin B resistant, zeocin resistant, kanamycin sensitive & This study \\
\hline \multicolumn{3}{|l|}{ B. mallei } \\
\hline ATCC 23344 & Wild-type strain; polymixin B resistant, zeocin sensitive, kanamycin sensitive & {$[75]$} \\
\hline bpaC KO & Isogenic bpaC mutant strain of ATCC 23344; polymixin B resistant, zeocin resistant, kanamycin sensitive & This study \\
\hline \multicolumn{3}{|l|}{ E. coli } \\
\hline EPI300 & Cloning strain & $\begin{array}{l}\text { epicentre }^{\circledast} \\
\text { lllumina }^{\circledast}\end{array}$ \\
\hline TUNER $^{\mathrm{TM}}$ & Expression strain for purification of His-tagged BpaC & EMD Millipore \\
\hline S17 & Strain used for conjugational transfer of pKASbpaC.zeo to B. pseudomallei and B. mallei & {$[76]$} \\
\hline $\mathrm{pCC} 1^{\mathrm{TM}}$ & Cloning vector, chloramphenicol resistant & $\begin{array}{l}\text { epicentre }^{\oplus} \\
\text { Illumina }^{\circledast}\end{array}$ \\
\hline pCCbpaC & pCC1 containing the B. pseudomallei DD503 bpaC gene, chloramphenicol resistant & This study \\
\hline pcCbpaC.zeo & $\begin{array}{l}\text { pCCbpaC in which a zeocin resistance cassette was introduced near the middle of the bpaC ORF; } \\
\text { chloramphenicol and zeocin resistant }\end{array}$ & This study \\
\hline pCC1.3 & pCC1-based plasmid control, does not confer adherence to human epithelial cells; chloramphenicol resistant & {$[77]$} \\
\hline pKAS46 & Mobilizable suicide plasmid; kanamycin resistant & {$[78]$} \\
\hline pKASbpaC.zeo & pKAS46 containing the insert from pCCbpaC.zeo & This study \\
\hline pEM7ZEO & Source of the zeocin resistance marker & $\begin{array}{l}\text { Life } \\
\text { Technologies }\end{array}$ \\
\hline $\begin{array}{l}\text { pELHisBPSL1631- } \\
\text { BMA1027 }\end{array}$ & $\begin{array}{l}\text { Plasmid expressing aa } 392-1068 \text { of B. pseudomallei 1026b BpaC fused to six N-terminal histidine residues, intro- } \\
\text { duced in E. coli TUNER and used to purify His-tagged BpaC protein for antibody production and ELISA experi- } \\
\text { ments; chloramphenicol resistant. }\end{array}$ & {$[67]$} \\
\hline
\end{tabular}


primers P1 (5'-ATA CCC AAA TCG GCG TTC TCT GGT-3') and P2 (5'-TGC GCG AAT CAA TCG AGA TAC CCA-3') and the PCR product was used as a template in sequencing reactions. The amplicon was also cloned in the vector $\mathrm{pCCl}^{\mathrm{Tm}}$ using the CopyControl ${ }^{\mathrm{m}}{ }^{\mathrm{m}}$ PCR cloning kit (epicentre ${ }^{\circ}$ Illumina ${ }^{\circ}$ ), producing the plasmid pCCbpaC (Table 3). The latter was sequenced to determine that PCR did not introduce mutations resulting in aa substitutions in the $b p a C$ gene product.

\section{Construction of isogenic mutant strains of $B$. mallei and $B$. pseudomallei}

The plasmid pCCbpaC was digested with the enzyme NsiI (New England BioLabs ${ }^{\circ}$, Inc.) to remove a $0.6-\mathrm{kb}$ fragment internal to the $b p a C$ ORF, treated with the End-It ${ }^{\text {ma }}$ DNA End Repair Kit (epicentre ${ }^{\odot}$ Illumina ${ }^{\circ}$ ), and ligated with a 0.4-kb zeocin resistance cassette to yield the construct pCCbpaC.zeo. This plasmid was restricted with BamHI (New England BioLabs ${ }^{\circ}$, Inc.) and a 3.4-kb fragment corresponding to the bpaC ORF disrupted by the insertion of the zeocin resistance cassette was excised from an agarose gel, purified with the High Pure PCR Product Purification kit (Roche Applied Science), and treated with the End-It ${ }^{\mathrm{mix}}$ DNA End Repair Kit. This blunt DNA fragment was then cloned in the suicide vector pKAS46. The resulting plasmid, designated pKASbpaC.zeo, was introduced in the E. coli strain S17 by electroporation, and subsequently transferred into $B$. mallei ATCC 23344 or B. pseudomallei DD503 by conjugation, as previously reported $[55,80]$. Upon conjugation, Burkholderia colonies were selected for resistance to zeocin. These putative mutants were then screened by PCR using Platinum ${ }^{\circ}$ Pfx DNA Polymerase with primers $\mathrm{P} 1$ and P2. The primers yielded a PCR product of $3.8-\mathrm{kb}$ in the parent strains and a smaller amplicon of 3.6-kb in bpaC mutants. The PCR products from mutant strains were sequenced to verify proper allelic exchange and successful disruption of bpaC.

\section{Nucleotide sequence and bioinformatic analyses}

PCR products and plasmids were sequenced at the University of Michigan Sequencing Core (http://seqcore. brcf.med.umich.edu). Chromatograms were assembled using the Sequencher 5 software (Gene Codes Corporation). Sequence analyses were performed using Vector NTI (Life Technologies $\left.^{\mathrm{mi}}\right)$ and the various online tools available through the EsPASy Bioinformatics Resource Portal (http://www.expasy.org). Signal sequence cleavage sites were determined using the SignalP 4.1 server (http://www. cbs.dtu.dk/services/SignalP). The B. mallei ATCC 23344 bpaC gene product (locus tag \# BMA1027) was identified by searching the genome of the organism for the presence of a YadA anchor domain (Pfam database number
PF3895.10) through the NCBI genomic BLAST service using the blastp program (http://www.ncbi.nlm.nih.gov/ sutils/genom_table.cgi). The other bpaC gene products described in this study were identified using the predicted aa sequence of the B. mallei ATCC $23344 \mathrm{BpaC}$ protein to search the genomes of the $B$. malle $i$ and $B$. pseudomallei strains available through the NCBI genomic BLAST service utilizing the tblastn and blastp programs. Structural features of the $\mathrm{BpaC}$ proteins (helical regions, hydrophobic $\beta$-strands) were identified with the PSIPRED Protein Sequence Analysis Workbench service (http://bioinf.cs.ucl.ac.uk/psipred/).

\section{Experiments with epithelial cells and J774 murine macrophages}

Adherence, invasion, and intracellular survival assays were performed as previously reported by our laboratory [53-55]. Cells were inoculated with bacteria at a multiplicity of infection (MOI) of 100. Duplicate assays were performed on at least 3 occasions. Statistical analyses were performed using the Mann-Whitney test (GraphPad Prism ${ }^{\circ} 6$ software) and $P$ values $<0.05$ are reported as statistically significant.

\section{Bactericidal assays}

The method used to examine the effect of bpaC mutations on the ability of Burkholderia to resist the bactericidal activity of complement is outlined elsewhere $[9,77,81]$. We used final concentrations of $50 \%$ and $25 \%$ serum in assays with B. pseudomallei and B. mallei, respectively.

\section{Protein preparations, western blot, purification of recombinant $\mathrm{BpaC}$ protein, and antibody production} Sarkosyl-insoluble OM protein preparations were obtained as described by Carlone et al. [82]. The methods used to prepare whole cell lysates and perform western blot experiments are described elsewhere [8,53,54,57,83,84]. His-tagged recombinant $\mathrm{BpaC}$ was obtained from cultures of $E$. coli TUNER carrying the plasmid pELHisBPSL1631BMA1027, as previously outlined by our laboratory [67]. To obtain polyclonal Abs directed against BpaC, the purified His-tagged protein was emulsified in Freund's adjuvants (SIGMA-ALDRICH ${ }^{\circ}$ ) and used to immunize female BALB/c mice as reported by Lafontaine and colleagues [85].

\section{Immunofluorescence labeling of $E$. coli and microscopy}

Expression of $\mathrm{BpaC}$ on the surface of $E$. coli recombinant bacteria was visualized by immunofluorescence microscopy as outlined by Balder et al. [55]. Briefly, paraformaldehydefixed $E$. coli cells were spotted onto glass slides. These bacteria were probed with $\alpha-\mathrm{BpaC}$ polyclonal Abs, followed by incubation with a goat $\alpha$-mouse antibody labeled with 
Alexa Fluor $546^{\circ}$ (Life Technologies ${ }^{\mathrm{Tm}}$ ) and the nucleic acid dye DAPI (Life Technologies ${ }^{\mathrm{Tm}}$ ). Slides were examined by microscopy using a Zeiss LSM 510 Meta confocal system.

\section{ELISA}

Duplicate wells of Immulon $^{\text {tw }} 2 \mathrm{HB}$ plates (Thermo Scientific Nunc) were coated overnight at $4 \mathrm{C}^{\circ}$ with $1 \mu \mathrm{g}$ of His-tagged BpaC. Excess unbound antigen was removed by washing the wells with $\mathrm{PBS}+0.05 \%$ Tween 20 (PBST), and the wells were then blocked with PBS + $0.05 \%$ containing $3 \%$ dry milk (blocking buffer) for 1 hour at room temperature. After washing with PBST, the wells were probed overnight at $4^{\circ} \mathrm{C}$ with sera from mice that survived acute aerosol infection with $B$. mallei ATCC 23344 and B. pseudomallei 1026b [67] diluted in blocking buffer. After this incubation, the wells were washed with PBST and incubated overnight with a goat $\alpha$-mouse antibody conjugated to Horse Radish Peroxidase (SouthernBiotech) diluted in blocking buffer. After washing off the excess secondary antibody with PBST, $100 \mu \mathrm{L}$ of the SureBlue ${ }^{\mathrm{Tm}}$ TMB Microwell Peroxidase Substrate (KPL) was added to the wells. Color development, which is indicative of Abs binding to $\mathrm{BpaC}$, was measured spectrophotometrically by determining the absorbance of well contents at a wavelength of $650 \mathrm{~nm}$.

\section{Animal experiments}

Female BALB/c mice (6-8 weeks of age) were purchased from Frederick National Laboratory for Cancer Research. The animals were anesthetized by injecting a dose of $250 \mathrm{mg} / \mathrm{kg}$ of 2,2,2 tribromoethanol (SIGMA-AL$\mathrm{DRICH}^{\circ}$ ) intraperitoneally. Once anesthetized, mice were inoculated intratracheally with $50 \mu \mathrm{L}$ of bacterial suspensions using a Microsprayer model I-1C (PennCentury ${ }^{\mathrm{Tm}}$ ) as previously reported by our laboratory [67]. Infected animals were monitored twice daily. Humane end-points were strictly observed. Mice exhibiting signs of moderate to severe discomfort were euthanized. This was accomplished by anesthetizing the animals with 2,2,2 tribromoethanol followed by cervical dislocation, in accordance with the AVMA Guidelines on euthanasia. Food and water were provided ad libitum. Analgesics were not used as they may have affected the experimental outcomes of the studies. Survival data were analyzed using the KaplanMeier method and the $\mathrm{LD}_{50}$ values were calculated according to Reed and Muench [86].

\section{Compliance and animal research ethic statements}

All experiments with live B. pseudomallei and B. mallei were performed inside a Class II Biosafety Cabinet in a BSL3 laboratory and in compliance with the rules and regulations of the U.S. Federal Select Agent Program. The experiments were approved by the University of Georgia's Institutional Biosafety Committee (IBC).
Animal experiments were carried out in strict accordance with the recommendations in the Guide for the Care and Use of Laboratory Animals of the National Institutes of Health. The experiments were approved by the University of Georgia's Institutional Animal Care and Use Committee (IACUC). All efforts were made to minimize animal suffering.

\section{Additional files}

\section{Additional file 1: Comparison of the structural features specified by $B$. pseudomallei and $B$. mallei bpaC gene products. \\ Additional file 2: Characteristics $^{\mathrm{a}}$ of BMA1027 orthologous genes and their encoded products.}

\section{Abbreviations}

aa: Amino acid; OM: Outer membrane; Oca: Oligomeric coiled-coil adhesin; Bp: Burkholderia pseudomallei; Bm: Burkholderia mallei; KO: Knock-out; Abs: Antibodies; LD 50 : Median lethal dose; LSLB: Low salt luria bertani; CFU: Colony forming units; ORF: Open reading frame; NHBE: Normal human bronchial epithelium.

\section{Competing interests}

$E R L, R B, F M$ and RJH do not have financial or non-financial competing interests. In the past five years, the authors have not received reimbursements, fees, funding, or salary from an organization that may in any way gain or lose financially from the publication of this manuscript, either now or in the future. Such an organization is not financing this manuscript. The authors do not hold stocks or shares in an organization that may in any way gain or lose financially from the publication of this manuscript, either now or in the future. The authors do not hold and are not currently applying for any patents relating to the content of the manuscript. The authors have not received reimbursements, fees, funding, or salary from an organization that holds or has applied for patents relating to the content of the manuscript. The authors do not have nonfinancial competing interests (political, personal, religious, ideological, academic, intellectual, commercial or any other) to declare in relation to this manuscript.

\section{Authors' contributions}

Conceived and designed the experiments: ERL and RJH. Performed the experiments: ERL, FM, RB. Analyzed the data: ERL, RB, RJH. Wrote the manuscript: ERL and $\mathrm{RJH}$. All authors read and approve the final manuscript.

\section{Acknowledgements}

The study was supported by NIAID award Al062775 to ERL and by institutional funds from the College of Veterinary Medicine at the University of Georgia (UGA) to ERL and RJH. We thank Donald Woods (University of Calgary) for providing strains. We thank Laura Wiese (UGA), Sean Buskirk (UGA), Lauren Snipes (UGA), Xiudan Gao (UGA) and Serena Lipski (University of Toledo) for technical assistance. We thank Shawn Zimmerman (UGA) and Tomislav Jelesijevic (UGA) for their assistance redacting the manuscript.

\section{Author details}

'Department of Infectious Diseases, University of Georgia College of Veterinary Medicine, 30602 Athens, GA, USA. ²Department of Veterinary Biosciences and Diagnostic Imaging, University of Georgia College of Veterinary Medicine, 30602 Athens, GA, USA.

Received: 31 December 2013 Accepted: 8 April 2014

Published: 14 April 2014

\section{References}

1. Capecchi B, Adu-Bobie J, Di Marcello F, Ciucchi L, Masignani V, Taddei A, Rappuoli R, Pizza M, Arico B: Neisseria meningitidis NadA is a new invasin which promotes bacterial adhesion to and penetration into human epithelial cells. Mol Microbiol 2005, 55(3):687-698. 
2. Roggenkamp A, Ackermann N, Jacobi CA, Truelzsch K, Hoffmann H, Heesemann J: Molecular analysis of transport and oligomerization of the Yersinia enterocolitica adhesin YadA. J Bacteriol 2003, 185(13):3735-3744.

3. Attia AS, Lafontaine ER, Latimer JL, Aebi C, Syrogiannopoulos GA, Hansen EJ: The UspA2 protein of Moraxella catarrhalis is directly involved in the expression of serum resistance. Infect Immun 2005, 73(4):2400-2410.

4. Farn JL, Strugnell RA, Hoyne PA, Michalski WP, Tennent JM: Molecular characterization of a secreted enzyme with phospholipase B activity from Moraxella bovis. J Bacteriol 2001, 183(22):6717-6720.

5. Lipski SL, Akimana C, Timpe JM, Wooten RM, Lafontaine ER: The Moraxella catarrhalis autotransporter McaP is a conserved surface protein that mediates adherence to human epithelial cells through its $\mathrm{N}$-terminal passenger domain. Infect Immun 2007, 75(1):314-324.

6. Timpe JM, Holm MM, Vanlerberg SL, Basrur V, Lafontaine ER: Identification of a Moraxella catarrhalis outer membrane protein exhibiting both adhesin and lipolytic activities. Infect Immun 2003, 71(8):4341-4350.

7. Maroncle NM, Sivick KE, Brady R, Stokes FE, Mobley HL: Protease activity, secretion, cell entry, cytotoxicity, and cellular targets of secreted autotransporter toxin of uropathogenic Escherichia coli. Infect Immun 2006, 74(11):6124-6134.

8. Bullard B, Lipski S, Lafontaine ER: Regions important for the adhesin activity of Moraxella catarrhalis Hag. BMC Microbiol 2007, 7:65.

9. Lipski SL, Holm MM, Lafontaine ER: Identification of a Moraxella catarrhalis gene that confers adherence to various human epithelial cell lines in vitro. FEMS Microbiol Lett 2007, 267(2):207-213.

10. Fexby S, Bjarnsholt T, Jensen PO, Roos V, Hoiby N, Givskov M, Klemm P: Biological Trojan horse: antigen 43 provides specific bacterial uptake and survival in human neutrophils. Infect Immun 2007, 75(1):30-34.

11. Stevens JM, Ulrich RL, Taylor LA, Wood MW, Deshazer D, Stevens MP, Galyov EE: Actin-binding proteins from Burkholderia mallei and Burkholderia thailandensis can functionally compensate for the actin-based motility defect of a Burkholderia pseudomallei bimA mutant. J Bacteriol 2005, 187(22):7857-7862.

12. Klemm $P$, Hjerrild L, Gjermansen M, Schembri MA: Structure-function analysis of the self-recognizing Antigen 43 autotransporter protein from Escherichia coli. Mol Microbiol 2004, 51(1):283-296.

13. Heras B, Totsika M, Peters KM, Paxman JJ, Gee CL, Jarrott RJ, Perugini MA, Whitten AE, Schembri MA: The antigen 43 structure reveals a molecular Velcro-like mechanism of autotransporter-mediated bacterial clumping. Proc Natl Acad Sci U S A 2014, 111(1):457-462.

14. Valle J, Mabbett AN, Ulett GC, Toledo-Arana A, Wecker K, Totsika M, Schembri MA, Ghigo JM, Beloin C: UpaG, a new member of the trimeric autotransporter family of adhesins in uropathogenic Escherichia coli. J Bacteriol 2008, 190(12):4147-4167.

15. Sherlock O, Schembri MA, Reisner A, Klemm P: Novel roles for the AIDA adhesin from diarrheagenic Escherichia coli: cell aggregation and biofilm formation. J Bacterio/ 2004, 186(23):8058-8065.

16. Cotter SE, Surana NK, 3rd St Geme JW: Trimeric autotransporters: a distinct subfamily of autotransporter proteins. Trends Microbiol 2005, 13(5):199-205.

17. Henderson IR, Navarro-Garcia F, Nataro JP: The great escape: structure and function of the autotransporter proteins. Trends Microbiol 1998, 6(9):370-378.

18. Stathopoulos C, Hendrixson DR, Thanassi DG, Hultgren SJ, 3rd St Geme JW, 3rd Curtiss R: Secretion of virulence determinants by the general secretory pathway in gram-negative pathogens: an evolving story. Microbes Infect 2000, 2(9):1061-1072.

19. Henderson IR, Navarro-Garcia F, Desvaux M, Fernandez RC, Ala'Aldeen D: Type V protein secretion pathway: the autotransporter story. Microbiol Mol Biol Rev 2004, 68(4):692-744.

20. Linke D, Riess T, Autenrieth IB, Lupas A, Kempf VA: Trimeric autotransporter adhesins: variable structure, common function. Trends Microbiol 2006, 14(6):264-270

21. Hoiczyk E, Roggenkamp A, Reichenbecher M, Lupas A, Heesemann J: Structure and sequence analysis of Yersinia YadA and Moraxella UspAs reveal a novel class of adhesins. Embo J 2000, 19(22):5989-5999.

22. Ciabattini A, Giomarelli B, Parigi R, Chiavolini D, Pettini E, Arico B, Giuliani MM, Santini L, Medaglini D, Pozzi G: Intranasal immunization of mice with recombinant Streptococcus gordonii expressing NadA of Neisseria meningitidis induces systemic bactericidal antibodies and local IgA. Vaccine 2008, 26(33):4244-4250.
23. Bowe F, Lavelle EC, McNeela EA, Hale C, Clare S, Arico B, Giuliani MM, Rae A, Huett A, Rappuoli R, Dougan G, Mills KH: Mucosal vaccination against serogroup $B$ meningococci: induction of bactericidal antibodies and cellular immunity following intranasal immunization with NadA of Neisseria meningitidis and mutants of Escherichia coli heat-labile enterotoxin. Infect Immun 2004, 72(7):4052-4060.

24. Liu DF, Mason KW, Mastri M, Pazirandeh M, Cutter D, Fink DL, 3rd St Geme JW, Zhu D, Green BA: The C-terminal fragment of the internal 110-kilodalton passenger domain of the Hap protein of nontypeable Haemophilus influenzae is a potential vaccine candidate. Infect Immun 2004, 72(12):6961-6968.

25. Cutter D, Mason KW, Howell AP, Fink DL, Green BA, 3rd St Geme JW: Immunization with Haemophilus influenzae Hap adhesin protects against nasopharyngeal colonization in experimental mice. J Infect Dis 2002, 186(8):1115-1121.

26. Alamuri P, Eaton KA, Himpsl SD, Smith SN, Mobley HL: Vaccination with proteus toxic agglutinin, a hemolysin-independent cytotoxin in vivo, protects against Proteus mirabilis urinary tract infection. Infect Immun 2009, 77(2):632-641.

27. Waag DM, Deshazer D: Glanders: New Insights into an old Disease. In Biological Weapons Defense: Infectious Diseases and Counterbioterrorism. Edited by Lindler LE LF, Korch GW. Totowa, New Jersey: Humana Press Inc; 2004.

28. Alibek K, Handelman S: Biohazard: The Chilling True Story of the Largest Covert Biological Weapons Programin the World. New York: Random House; 1999.

29. Lehavi O, Aizenstien O, Katz LH, Hourvitz A: [Glanders-a potential disease for biological warfare in humans and animals]. Harefuah 2002, 141:119. Spec No:88-91.

30. Wheelis M: First shots fired in biological warfare. Nature 1998, 395(6699):213.

31. Wheelis M: Biological Sabotage in World War I. In Biological and Toxin Weapons: Research, Development, and use from the Middle Ages to 1945. Edited by Geissler EMoon JEC. Oxford: Oxford University Press; 1999:35-72.

32. Bondi SK, Goldberg JB: Strategies toward vaccines against Burkholderia mallei and Burkholderia pseudomallei. Expert Rev Vaccines 2008, 7(9):1357-1365.

33. Galyov EE, Brett PJ, Deshazer D: Molecular insights into Burkholderia pseudomallei and Burkholderia mallei pathogenesis. Annu Rev Microbiol 2010, 64:495-517.

34. Arun $S$, Neubauer $H$, Gurel A, Ayyildiz G, Kuscu B, Yesildere T, Meyer H, Hermanns W: Equine glanders in Turkey. Vet Rec 1999, 144(10):255-258.

35. Neubauer $\mathrm{H}$, Meyer $\mathrm{H}$, Finke EJ: Human glanders. Revue Internationale des Services de Sante des Forces Armees 1997, 70:258-265.

36. Whitlock GC, Estes DM, Torres AG: Glanders: off to the races with Burkholderia mallei. FEMS Microbiol Lett 2007, 277(2):115-122.

37. Srinivasan A, Kraus CN, DeShazer D, Becker PM, Dick JD, Spacek L, Bartlett $J G$, Byrne WR, Thomas DL: Glanders in a military research microbiologist. N Engl J Med 2001, 345(4):256-258.

38. Gregory BC, Waag DM: Glanders. In Medical Aspects of Biological Warfare, U. S Army Medical Department Borden Insitute Textbooks of Biological Warfare. Washington DC: Borden Institute Walter Reed Army Medical Center; 2007:121-146.

39. Cheng AC, Currie BJ: Melioidosis: epidemiology, pathophysiology, and management. Clin Microbiol Rev 2005, 18(2):383-416.

40. Wiersinga WJ, Currie BJ, Peacock SJ: Melioidosis. N Engl J Med 2012, 367(11):1035-1044

41. Wiersinga WJ, van der Poll T, White NJ, Day NP, Peacock SJ: Melioidosis: insights into the pathogenicity of Burkholderia pseudomallei. Nat Rev Microbiol 2006, 4(4):272-282.

42. Currie BJ, Fisher DA, Howard DM, Burrow JN, Lo D, Selva-Nayagam S, Anstey NM, Huffam SE, Snelling PL, Marks PJ Stephens DP, Lum GD, Jacups SP, Krause VL: Endemic melioidosis in tropical northern Australia: a 10-year prospective study and review of the literature. Clin Infect Dis 2000, 31(4):981-986

43. Currie BJ, Fisher DA, Anstey NM, Jacups SP: Melioidosis: acute and chronic disease, relapse and re-activation. Trans R Soc Trop Med Hyg 2000, 94(3):301-304.

44. Adler NR, Govan B, Cullinane M, Harper M, Adler B, Boyce JD: The molecular and cellular basis of pathogenesis in melioidosis: how does Burkholderia pseudomallei cause disease? FEMS Microbiol Rev 2009, 33(6):1079-1099. 
45. Vietri NJ, Deshazer D: Melioidosis. In Medical Aspects of Biological Warfare, U. S Army Medical Department Borden Insitute Textbooks of Biological Warfare. Washington DC: Borden Institute Walter Reed Army Medical Center; 2007:147-166.

46. Dance DA: Melioidosis as an emerging global problem. Acta Trop 2000, 74(2-3):115-119.

47. Rolim DB, Vilar DC, Sousa AQ, Miralles IS, de Oliveira DC, Harnett G, O'Reilly L, Howard K, Sampson I, Inglis TJ: Melioidosis, northeastern Brazil. Emerg Infect Dis 2005, 11(9):1458-1460.

48. Lipsitz R, Garges S, Aurigemma R, Baccam P, Blaney DD, Cheng AC, Currie BJ, Dance DA, Gee JE, Larsen J, Limmathurotsakul D, Morrow MG, Norton R, O'Mare E, Peacock SJ, Pesik N, Rogers LP, Schweizer HP, Steinmetz I, Tan G, Tan P, Wiersinga WJ, Wuthiekanun V, Smith TL: Workshop on Treatment of and Postexposure Prophylaxis for Burkholderia pseudomallei and B. mallei infection, 2010. Emerg Infect Dis 2012, 18(12). online report.

49. Lazar Adler NR, Stevens JM, Stevens MP, Galyov EE: Autotransporters and their role in the virulence of Burkholderia pseudomallei and Burkholderia mallei. Front Microbiol 2011, 2:151.

50. Campos CG, Borst L, Cotter PA: Characterization of BcaA, a putative classical autotransporter protein in Burkholderia pseudomallei. Infect Immun 2013, 81(4):1121-1128.

51. Campos CG, Byrd MS, Cotter PA: Functional characterization of Burkholderia pseudomallei trimeric autotransporters. Infect Immun 2013, 81(8):2788-2799.

52. Nummelin $H$, Merckel MC, Leo JC, Lankinen H, Skurnik M, Goldman A: The Yersinia adhesin YadA collagen-binding domain structure is a novel left-handed parallel beta-roll. Embo J 2004, 23(4):701-711.

53. Bullard B, Lipski SL, Lafontaine ER: Hag directly mediates the adherence of Moraxella catarrhalis to human middle ear cells. Infect Immun 2005, 73(8):5127-5136

54. Balder R, Krunkosky TM, Nguyen CQ, Feezel L, Lafontaine ER: Hag mediates adherence of Moraxella catarrhalis to ciliated human airway cells. Infect Immun 2009, 77(10):4597-4608.

55. Balder R, Lipski S, Lazarus JJ, Grose W, Wooten RM, Hogan RJ, Woods DE, Lafontaine ER: Identification of Burkholderia mallei and Burkholderia pseudomallei adhesins for human respiratory epithelial cells. BMC Microbiol 2010, 10:250.

56. Lazar Adler NR, Dean RE, Saint RJ, Stevens MP, Prior JL, Atkins TP, Galyov EE: Identification of a Predicted Trimeric Autotransporter Adhesin Required for Biofilm Formation of Burkholderia pseudomallei. PLoS One 2013, 8(11):e79461.

57. Cope LD, Lafontaine ER, Slaughter CA, Hasemann CA Jr, Aebi C, Henderson FW, McCracken GH Jr, Hansen EJ: Characterization of the Moraxella catarrhalis uspA1 and uspA2 genes and their encoded products. J Bacteriol 1999, 181(13):4026-4034.

58. Brooks MJ, Sedillo JL, Wagner N, Laurence CA, Wang W, Attia AS, Hansen EJ, Gray-Owen SD: Modular arrangement of allelic variants explains the divergence in Moraxella catarrhalis UspA protein function. Infect Immun 2008, 76(11):5330-5340.

59. Brooks MJ, Sedillo JL, Wagner N, Wang W, Attia AS, Wong H, Laurence CA, Hansen EJ, Gray-Owen SD: Moraxella catarrhalis binding to host cellular receptors is mediated by sequence-specific determinants not conserved among all UspA1 protein variants. Infect Immun 2008, 76(11):5322-5329.

60. Lafontaine ER, Cope LD, Aebi C, Latimer JL, McCracken GH Jr, Hansen EJ: The UspA1 protein and a second type of UspA2 protein mediate adherence of Moraxella catarrhalis to human epithelial cells in vitro. J Bacteriol 2000, 182(5):1364-1373.

61. Moore RA, DeShazer D, Reckseidler S, Weissman A, Woods DE: Effluxmediated aminoglycoside and macrolide resistance in Burkholderia pseudomallei. Antimicrob Agents Chemother 1999, 43(3):465-470.

62. Balder R, Hassel J, Lipski S, Lafontaine ER: Moraxella catarrhalis strain O35E expresses two filamentous hemagglutinin-like proteins that mediate adherence to human epithelial cells. Infect Immun 2007, 75(6):2765-2775.

63. Krunkosky TM, Fischer BM, Martin LD, Jones N, Akley NJ, Adler KB: Effects of TNF-alpha on expression of ICAM-1 in human airway epithelial cells in vitro. Signaling pathways controlling surface and gene expression. Am J Respir Cell Mol Biol 2000, 22(6):685-692.

64. Krunkosky TM, Jordan JL, Chambers E, Krause DC: Mycoplasma pneumoniae host-pathogen studies in an air-liquid culture of differentiated human airway epithelial cells. Microb Pathog 2007, 42(2-3):98-103.
65. Pearson MM, Hansen EJ: Identification of gene products involved in Biofilm production by Moraxella catarrhalis ETSU-9 in vitro. Infect Immun 2007, 75(9):4316-4325.

66. Wang W, Pearson MM, Attia AS, Blick RJ, Hansen EJ: A UspA2H-negative variant of Moraxella catarrhalis strain $\mathrm{O} 46 \mathrm{E}$ has a deletion in a homopolymeric nucleotide repeat common to uspA2H genes. Infect Immun 2007, 75(4):2035-2045.

67. Lafontaine ER, Zimmerman S, Shaffer TL, Michel F, Gao X, Hogan RJ: Use of a safe, reproducible and rapid aerosol delivery method to study infection by Burkholderia pseudomallei and Burkholderia mallei in mice. PLoS One 2013, 8(10):e76804.

68. Stevens MP, Stevens JM, Jeng RL, Taylor LA, Wood MW, Hawes P, Monaghan P, Welch MD, Galyov EE: Identification of a bacterial factor required for actin-based motility of Burkholderia pseudomallei. Mol Microbiol 2005, 56(1):40-53

69. Mima T, Schweizer HP: The BpeAB-OprB efflux pump of Burkholderia pseudomallei $1026 \mathrm{~b}$ does not play a role in quorum sensing, virulence factor production, or extrusion of aminoglycosides but is a broad-spectrum drug efflux system. Antimicrob Agents Chemother 2010, 54(8):3113-3120

70. Tiyawisutsri R, Holden MT, Tumapa S, Rengpipat S, Clarke SR, Foster SJ, Nierman WC, Day NP, Peacock SJ: Burkholderia Hep_Hap autotransporter (BuHA) proteins elicit a strong antibody response during experimental glanders but not human melioidosis. BMC Microbiol 2007, 7:19.

71. Goodyear A, Bielefeldt-Ohmann H, Schweizer H, Dow S: Persistent gastric colonization with Burkholderia pseudomallei and dissemination from the gastrointestinal tract following mucosal inoculation of mice. PLOS One 2012, 7(5):e37324.

72. Revelli DA, Boylan JA, Gherardini FC: A non-invasive intratracheal inoculation method for the study of pulmonary melioidosis. Front Cell Infect Microbiol 2012, 2:164

73. Hoppe I, Brenneke B, Rohde M, Kreft A, Haussler S, Reganzerowski A, Steinmetz I: Characterization of a murine model of melioidosis: comparison of different strains of mice. Infect Immun 1999, 67(6):2891-2900.

74. Leakey AK, Ulett GC, Hirst RG: BALB/C and C57BI/6 mice infected with virulent Burkholderia pseudomallei provide contrasting animal models for the acute and chronic forms of human melioidosis. Microb Pathog 1998, 24(5):269-275.

75. Nierman WC, DeShazer D, Kim HS, Tettelin H, Nelson KE, Feldblyum T, Ulrich RL, Ronning CM, Brinkac LM, Daugherty SC, Davidsen TD, Deboy RT, Dimitrov G, Dodson RJ, Durkin AS, Gwinn ML, Haft DH, Khouri H, Kolonay JF, Madupu R, Mohammoud Y, Nelson WC, Radune D, Romero CM, Sarria S, Selengut J, Shamblin C, Sullivan SA, White O, Yu Y, et al: Structural flexibility in the Burkholderia mallei genome. Proc Natl Acad Sci U S A 2004, 101(39):14246-14251.

76. Simon $R$, Priefer $U$, Puhler A: A broad host range mobilisation system for in vivo genetic engineering: transposon mutagenesis in gram-negative bacteria. Bio/Technology 1983, 1:784-791.

77. Holm MM, Vanlerberg SL, Foley IM, Sledjeski DD, Lafontaine ER: The Moraxella catarrhalis porin-like outer membrane protein $C D$ is an adhesin for human lung cells. Infect Immun 2004, 72(4):1906-1913.

78. Skorupski K, Taylor RK: Positive selection vectors for allelic exchange. Gene 1996, 169(1):47-52.

79. Sambrook J, Russell DW: Molecular Cloning: A Laboratory Manual (Third Edition). 3rd edition. Woodbury NY: Cold Spring Harbor Laboratory Press; 2001.

80. Burtnick M, Bolton A, Brett P, Watanabe D, Woods D: Identification of the acid phosphatase (acpA) gene homologues in pathogenic and nonpathogenic Burkholderia spp. facilitates TnphoA mutagenesis. Microbiology 2001, 147(Pt 1):111-120.

81. Aebi C, Lafontaine ER, Cope LD, Latimer JL, Lumbley SL, McCracken GH Jr, Hansen EJ: Phenotypic effect of isogenic uspA1 and uspA2 mutations on Moraxella catarrhalis 035E. Infect Immun 1998, 66(7):3113-3119.

82. Carlone GM, Thomas ML, Rumschlag HS, Sottnek FO: Rapid microprocedure for isolating detergent-insoluble outer membrane proteins from Haemophilus species. J Clin Microbiol 1986, 24(3):330-332.

83. Shaffer TL, Balder R, Buskirk SW, Hogan RJ, Lafontaine ER: Use of the Chinchilla model to evaluate the vaccinogenic potential of the Moraxella catarrhalis filamentous hemagglutinin-like proteins MhaB1 and MhaB2. PLoS One 2013, 8(7):e67881. 
84. Patrick CC, Kimura A, Jackson MA, Hermanstorfer L, Hood A, McCracken GH $\mathrm{Jr}$, Hansen EJ: Antigenic characterization of the oligosaccharide portion of the lipooligosaccharide of nontypable Haemophilus influenzae. Infect Immun 1987, 55(12):2902-2911.

85. Lafontaine ER, Wagner NJ, Hansen EJ: Expression of the Moraxella catarrhalis UspA1 protein undergoes phase variation and is regulated at the transcriptional level. J Bacteriol 2001, 183(5):1540-1551.

86. Reed $\sqcup$, Muench $\mathrm{H}$ : A simple method for estimating fifty percent end points. Am J Hyg 1938, 27:793-497.

doi:10.1186/1471-2180-14-92

Cite this article as: Lafontaine et al:: Characterization of an autotransporter adhesin protein shared by Burkholderia mallei and Burkholderia pseudomallei. BMC Microbiology 2014 14:92.

\section{Submit your next manuscript to BioMed Central and take full advantage of:}

- Convenient online submission

- Thorough peer review

- No space constraints or color figure charges

- Immediate publication on acceptance

- Inclusion in PubMed, CAS, Scopus and Google Scholar

- Research which is freely available for redistribution 